\title{
The gut as a sensory organ
}

\section{John B. Furness, Leni R. Rivera, Hyun-Jung Cho, David M. Bravo and Brid Callaghan}

Abstract | The gastrointestinal tract presents the largest and most vulnerable surface to the outside world. Simultaneously, it must be accessible and permeable to nutrients and must defend against pathogens and potentially injurious chemicals. Integrated responses to these challenges require the gut to sense its environment, which it does through a range of detection systems for specific chemical entities, pathogenic organisms and their products (including toxins), as well as physicochemical properties of its contents. Sensory information is then communicated to four major effector systems: the enteroendocrine hormonal signalling system; the innervation of the gut, both intrinsic and extrinsic; the gut immune system; and the local tissue defence system. Extensive endocrine-neuro-immune-organ-defence interactions are demonstrable, but under-investigated. A major challenge is to develop a comprehensive understanding of the integrated responses of the gut to the sensory information it receives. A major therapeutic opportunity exists to develop agents that target the receptors facing the gut lumen.

Furness, J. B. et al. Nat. Rev. Gastroenterol. Hepatol. advance online publication. XX Month 2013; doi:10.1038/

Department of Anatomy \& Neuroscience, University of Melbourne, Grattan Street, Parkville, VIC 3010, Australia (J. B. Furness, L. R. Rivera, H.-J. Cho, B. Callaghan). Pancosma S. A., Voie-des-Traz 6, Geneva 1218, Switzerland (D. M. Bravo).

Correspondence to:

J. B Furness

¡.furness@unimelb.edu.au

Competing interests

The authors declare no competing interests.

Key points

The lining of the digestive tract is exposed to an extraordinarily broad range of chemicals and organisms

The gut continuously monitors the composition of its contents to optimize digestion and absorption, and to ward off threats to its integrity

The gut has numerous sensors that detect nutrients, distension, symbiotic and pathogenic microorganisms, toxins and other components of its luminal contents

For the digestive system to react appropriately to its environment, the sensory information is communicated to extensive endocrine, neural, immune and nonimmune tissue defence systems

More than 20 receptors that face the luminal contents are potential therapeutic targets for diabetes, obesity and digestive disorders; restricting orally active therapeutics to the lumen could reduce off-target actions

Introduction

The content of the intestine is rich in chemicals and microorganisms. This complex 'soup' is an external milieu, separated from the body's internal milieu by only a single layer of epithelial cells for most of the length of the gastrointestinal tract, the oesophagus alone having a multilayered epithelial barrier. The human small intestine presents a surface membrane area of $\sim 60 \mathrm{~m}^{2}$ to its contents, making it the largest vulnerable surface of the body, ${ }^{1}$ and, when the stomach and colon are included, the total surface of the gastrointestinal tract that faces the external environment is $\sim 100 \mathrm{~m}^{2}$, with some estimates up to $400 \mathrm{~m}^{2}$, compared with only $2 \mathrm{~m}^{2}$ of skin., The external milieu (the luminal content of the gut) is continually modified by: ingestion of food and drink, as well as any contaminants they might bring with them; replication of microorganisms; microbial products; enzymatic and chemical breakdown of complex molecules; gastrointestinal secretions; potentially toxic chemicals; and pharmaceuticals. The intestine continuously monitors the composition of its contents to optimize assimilation of nutrients and to ward off threats to its integrity. Thus, the intestine is endowed with a range of sensory receptors (listed in Box 1) that activate four major effector systems-the enteroendocrine system, the nervous system, the gut immune system, and the nonimmune defence systems of the gut (Figures 1, 2).

A flood of new information has been reported about the sensory receptors expressed by 
enteroendocrine cells, roles of intrinsic and extrinsic sensory neurons, the gut microbiome and its relationship with the host, and a range of nonimmune defence mechanisms. Nevertheless, the gut endocrine system, gastrointestinal innervation and gut defences tend to be treated separately by investigators and commentators. Here, we draw together discoveries of the past 5-10 years relevant to sensing by the intestine and advance the idea that these detection systems and their effectors need to be investigated together in the context of the gut as a sensory organ. The digestive tract also senses messages from the internal environment, including hormones released by cells in other gut regions, hormones from other sources, cytokines and neural signals, including those from the central nervous system (CNS).

The presence of receptors that face the lumen and are responsive to luminal contents provides a unique therapeutic opportunity. Targeting these receptors with pharmaceutical agents that remain restricted to the lumen has the potential to provide gut-directed therapies without the adverse effects caused by actions of these agents at systemic sites. ${ }^{4}$

\section{Enteroendocrine cells and nutrients}

Nutrient receptors are mostly, but not exclusively, located on enteroendocrine cells; collectively, these cells form our largest endocrine organ. ${ }^{5,6}$ Approximately 12 major enteroendocrine cell types have been identified, which collectively secrete $>20$ hormones (listed in Table 1). The hormones released by enteroendocrine cells can act locally, on other cells (including immune cells), nerve endings, or organs at remote sites including pancreatic islets and the CNS. The effects that are exerted through nutrient receptors on enteroendocrine cells include changes in food intake (appetite and satiety), changes in gastric emptying and intestinal transit, release of digestive enzymes, induction of nutrient transporters and digestive enzymes, an increase in intestinal barrier function, pancreatic insulin secretion, modulation of immune responses and tissue growth.

Classic taste receptors

Taste receptors of the types previously characterized in the oral cavity were first reported in the intestine in 2002. ${ }^{7}$ The receptors are G protein-coupled receptors (GPCRs) of two classes, taste receptor type 1 (T1R) and taste receptor type 2 (T2R). ${ }^{8,9}$ Two receptors are formed by GPCRs of the T1R family, the sweet taste receptor, a T1R2-T1R3 heterodimer, and the umami (savoury) receptor, a T1R1-T1R3 heterodimer. By contrast, the bitter receptor family, T2R, is represented by >30 known GPCRs. The sweet, umami and bitter receptors are coupled through the G-protein $\alpha$-gustducin, which is expressed by $\mathrm{A}, \mathrm{K}$ and $\mathrm{L}$ cells (Table 1$)^{8,9}$ Although this observation implies that classic taste receptors operate through these enteroendocrine cell types, ${ }^{6,10}$ evidence now indicates that classic taste receptors are not the primary detectors of sugars in the intestine (discussed later). The sour receptor is not a T1R or T2R; a family of sour receptors possibly exists, one of which is PKD2L1, a member of the transient receptor potential (TRP) family of ligand-gated ion channels. ${ }^{11,12}$

Sweet taste receptors are broadly tuned to detect glucose and other simple sugars, and are also activated by artificial sweeteners. In the distal small intestine, a sweet taste receptor-like receptor, which includes T1R3 in its structure, is expressed by L cells, and its activation by glucose releases L-cell hormones, ${ }^{13,14}$ including the incretin, glucagon-like peptide 1 (GLP-1). ${ }^{15,16}$ Agonists of GLP-1 receptors and inhibitors of GLP-1 metabolism are used in the treatment of type 2 diabetes (T2D). ${ }^{17}$

Glucose-stimulated GLP-1 secretion (GSGS) is severely impaired in T1r3-knockout rodents. ${ }^{14}$ However, when the other component of the sweet taste receptor heterodimer, T1r2, was knocked out, mice showed normal glycaemic control and GSGS, suggesting that T1r3 can mediate GSGS without forming a fully constituted sweet taste receptor. Strong evidence indicates that sodium-glucose cotransporter 1 (SGLT1, also known as SLC5A1) has a major role in GSGS; an 80\% reduction in GSGS was observed in Sglt1-knockout mice. ${ }^{18,19}$ Taken together, these data suggest that T1R3 and SGLT1 might interact in L cells. Glucose-stimulated secretion of glucagon-like insulinotropic peptide (GIP) from K cells in the proximal intestine is also SGLT1-dependent, but whether taste receptors have a role in this process is not yet resolved. ${ }^{9,19,20} \mathrm{~L}$ cells also release GLP-2, which indirectly induces expression and activates SGLT1 in enterocytes, as well as increasing absorption of amino acids (leucine was used as an indicator) and triglyceride (triolein), and markedly increasing the activities of digestive enzymes (including maltase, sucrase and lactase). ${ }^{21-23}$

The presence of umami receptors in the stomach and intestines is suggested by the effects of umami 
receptor stimulants. ${ }^{24}$ T1R3, a component of both sweet and umami receptors, has been localized to ghrelin-containing A cells in the stomach and also to brush cells-specialized epithelial cells proposed to have a sensory role in the gut. ${ }^{25}$ As no evidence indicates that sweet taste receptors are expressed by A cells - in fact, T1R2 does not seem to be expressed in the stomach at all - ${ }^{26}$ A cells are thought to express umami receptors. Cholecystokinin (CCK)-releasing I cells also have umami receptors. ${ }^{27}$ Agonists of bitter receptors cause ghrelin release, implying that A cells also express members of the T2R family. ${ }^{28}$

\section{Free fatty acid receptors}

Fats, because of their low water solubility, present a greater challenge to digestion than proteins or carbohydrates, and are generally thought to be rate limiting in the time taken to digest a meal. ${ }^{29}$ Fats initiate release of bile salts for emulsification, release of lipases to break them down, slowing of intestinal transit to provide time for their digestion, and satiety. Fats initiate these processes by activating GPCRs: free fatty acid receptor 1 (FFAR1, also known as GPR40), FFAR2 (also known as GPR43), FFAR3 (also known as GPR41), GPR119 (which binds to free fatty acid metabolites, including fatty acylethanolamides) and GPR120. FFARs also react to fatty acids that are produced by bacteria, especially in the colon. Investigation of the relative roles of fatty acid receptors is an active area, and the state of knowledge is incomplete. However, as summarized below, some basic facts are emerging in relation to specific control exerted through receptors for fatty acids.

Fats and digestive enzyme release

CCK is the major hormone involved in the release of digestive enzymes in response to fats, which is released from FFAR1-expressing I cells in the upper small intestine. ${ }^{30}$ CCK, released promptly by short-chain and medium-chain fatty acids, excites mucosal endings of vagal afferent neurons that express the CCK- 1 receptor. ${ }^{31}$ The vagal afferent signals are then conveyed to the nucleus tractus solitarius in the brain stem (medulla) and the resultant output, which is modified by other sensory information reaching the medulla, activates vagal efferent pathways that innervate the gallbladder and the pancreas. Circulating CCK can also contribute to gallbladder contraction by enhancing transmission from vagal efferent nerve endings. ${ }^{32}$ In the exocrine pancreas, physiological levels of CCK activate a vago-vagal reflex to promote enzyme secretion, whereas greater, possibly supraphysiological, levels of CCK act directly on the pancreas to trigger enzyme release. ${ }^{33}$

Although fats trigger CCK release from I cells, CCK promotes release of amylases, proteases and lipases from the pancreas. ${ }^{6}$ Thus, lipid in the small intestine promotes digestion of all major food components. Of note, I cells also express umami receptors ${ }^{27}$ and the aromatic amino-acid responsive calcium-sensitive receptor. ${ }^{27,34}$ Glucose infusion into the stomach or small intestine also stimulates CCK release in humans. ${ }^{16,35}$ However, lactisole, a T1R3 blocker, does not alter glucose-induced or emulsified fat-induced. CCK release in humans, suggesting that I cells do not express functional sweet taste receptors. ${ }^{16}$ Free fatty acids also cause the release of insulinotropic hormones, including GIP from K cells and GLP-1 from L cells. ${ }^{36}$ Release of GLP-1 is mediated by FFAR2 and fatty acid transport protein 4 (FATP4). ${ }^{37,38}$

\section{Fats and intestinal transit: the ileal brake}

L cells express the complete range of fatty acid receptors, ${ }^{4,39-41}$ and fats trigger release of peptide YY (PYY) and GLP-1 from L cells. One effect of PYY is to activate a neural circuit that inhibits propulsive activity in the proximal intestine (duodenum and jejunum). ${ }^{33,42} \mathrm{PYY}$ therefore acts as a local hormone to activate the intestinofugal nerve pathway that passes via sympathetic prevertebral ganglia to the proximal small intestine and stomach (Figure 3). GLP-1 also contributes to inhibition of proximal regions, the major effects being inhibition of gastric emptying and gastric acid secretion, mediated through vago-vagal reflexes. ${ }^{43}$

\section{Fats and satiety}

Lipids are the most energy dense of the major food types, providing $\sim 9 \mathrm{cal} / \mathrm{g}$ or $38 \mathrm{~kJ} / \mathrm{g}$, and the most satiating. CCK, released from I cells, and three products of L cells (namely, GLP-1, oxyntomodulin and PYY) are satiety factors. ${ }^{44}$ The satiety effects of CCK, GLP-1 and oxyntomodulin are mediated through the vagus nerve, although direct effects on the hypothalamus can also be demonstrated. ${ }^{31,45,46}$ PYY acts directly on the hypothalamus and also triggers CCK release, which indirectly contributes to the satiety effect of PYY via CCK-mediated activation of the vagus. ${ }^{31,47}$ 
Receptors for proteins and their products

Proteins are broken down by acid hydrolysis and proteases to produce peptones, tripeptides and dipeptides and individual amino acids. GLP-1 is released only by the presence of digested proteins, suggesting that $\mathrm{L}$ cells express peptone receptors. ${ }^{48}$ Although peptone receptors have not yet been localized to L cells, they do occur in the stomach, where the peptone receptor LPAR5 (also known as GPR92 and GPR93) has been located in G cells and D cells. ${ }^{49} \mathrm{G}$ cells, and a small proportion of D cells, also express GPRC6A, which responds to basic amino acids, including arginine, lysine and ornithine. $^{50}$ The umami receptor, which is activated by glutamate, is expressed by gastric A cells and by I cells in the small intestine. Further investigation of the distributions and functions of receptors for proteins and protein fragments is needed.

\section{Enteroendocrine hormones in tissue defence}

The established role of the L-cell hormone GLP-2 is regulation of intestinal absorptive capacity, in part by enhancing mucosal growth. ${ }^{4,51}$ However, it also regulates mucosal defence, in particular by anti-inflammatory effects that are mediated through the stimulation of submucosal neurons containing vasoactive intestinal peptide and the release of the tissue repair factors, keratinocyte growth factor and, possibly, insulin-like growth factor. ${ }^{52-54} \mathrm{An}$ increase in intestinal barrier function mediated by GLP-2 also contributes to mucosal protection. ${ }^{55}$ Indeed, deletion of Glp2r in mice increases the severity of indomethacin-induced enteritis and the degree of bacterial translocation in the small intestine ${ }^{56}$ These mice also display decreased expression of genes encoding antimicrobial products in Paneth cells and reduced mucosal antibacterial capacity, although Paneth cell numbers remained unchanged. ${ }^{56}$ GLP-2 increases intestinal blood flow, which could facilitate digestion and absorption of nutrients and tissue repair. ${ }^{57}$

Consistent with roles in tissue defence, enteroendocrine cells express Toll-like receptors (TLRs). TLR1 and TLR2 were found to be localized on enteroendocrine cells containing 5-hydroxytryptamine (5-HT; serotonin) in tissue sections; STC1 (a mouse-derived CCK-containing enteroendocrine cell line) was shown to express TLRs and to respond to both lipopolysaccharide (LPS) and synthetic bacterial lipoprotein. ${ }^{58,59}$ Moreover, serum CCK levels were elevated after oral administration of LPS or other activators of TLRs. ${ }^{59}$ The human CCK-expressing enteroendocrine cell line, LCC-18, also responds to activation of TLRs. ${ }^{60}$

Phytochemical receptors

Certain plants, whose characteristic odours and tastes are manifested though odorant receptors, also contain chemicals (including odorants) that act on receptors in the digestive tract. ${ }^{61,62}$ In most cases such plants are classified as herbs or spices. Receptors for these phytochemicals are generally overlooked in reviews that deal with chemosensing in the gut, ${ }^{6,8}$ an exception being an excellent review published in 2011 by Holzer. ${ }^{61}$ Thus, the field is under-researched, despite the fact that herbs and spices are commonly included in human and animal food, and are often regarded as additives that improve digestion. $^{63}$

An identified family of phytochemical receptors in the gut are TRP receptors-ligand-gated ion channels that provide an inward cation current, including $\mathrm{Ca}^{2+}$ entry, when activated. 28 channels (some of which have several isoforms) have been identified, grouped according to molecular similarities into seven families. ${ }^{64}$ TRP receptors have critical roles in sensory physiology, which include contributions to vision, taste, olfaction, hearing, touch, thermosensation and osmosensation. ${ }^{64}$ 8 of 28 TRPs have been identified in the gut, ${ }^{61}$ but we have further investigated their expression and have found that genes for all 28 are expressed in the mouse gastrointestinal mucosa (B. Callaghan, H.-J. Cho and J. B. Furness, unpublished data).

The TRPA1 receptor has been localized to overlapping populations of enteroendocrine cells in the small intestine that express CCK and 5-HT, and also to enteroendocrine-derived cell lines. ${ }^{65,66}$ Phytochemicals that activate this receptor include allyl isothiocyanate (from wasabi and mustard) and cinnamaldehyde (from cinnamon). ${ }^{61}$ Allyl isothiocyanate led to release of CCK from STC1 cells ${ }^{65}$ and 5-HT release from isolated enteroendocrine cells. ${ }^{66}$ Combined in situ hybridization histochemistry and immunohistochemistry shows co-localization of TRPA1 expression and 5-HT in mouse and human 
endocrine cells. ${ }^{66}$

The TRPM5 ion channel has a special role in taste perception, as it is associated with bitter, sweet and umami taste receptors. TRPM5, a $\mathrm{Ca}^{2+}$-sensitive cation channel that is activated when levels of cytoplasmic $\mathrm{Ca}^{2+}$ downstream from $\alpha$-gustducin are elevated, leads to cell depolarization and potentiates gut hormone release. ${ }^{67}$ Trpm5-null mice have reduced responses to bitter, sweet and umami compounds, indicating that Trpm5 has a role in amplifying responses of each receptor, but that Trpm5-independent sensing of these tastes can still occur. ${ }^{68}$ Of interest, odorant receptors are also expressed in the epithelial cells that line the intestine. One such receptor is olfactory receptor $1 \mathrm{G} 1,{ }^{69,70}$ which is sensitive to thymol-an activator of TRPA1 and TRPV3.

\section{Clinical implications}

There is potential to develop orally active, luminally restricted compounds that target enteroendocrine cell receptors, but do not enter the systemic circulation to cause off-target effects. ${ }^{4}$ One such target is receptors on L cells that cause release of GLP-1. Indeed, a current effective therapy for T2D is direct targeting of GLP-1 receptors on pancreatic $\beta$ cells with exenatide. ${ }^{71}$ Another target receptor under investigation is GPR119, which is expressed by L cells and pancreatic $\beta$ cells. ${ }^{72}$ GPR119 agonists both increase GLP-1 release and act directly on pancreatic islets to release insulin. Therapeutics that specifically release endogenous GLP- 1 from L cells are not yet available, ${ }^{20}$ although a luminally restricted GPR119 agonist might be selective for incretin secretion. Another possibility is to target receptors for free fatty acids on enteroendocrine cells to increase satiety and combat obesity. ${ }^{4}$ SGLT1 or mechanisms through which its expression is regulated are also a possible antidiabetic targets. ${ }^{73}$ SGLT1 is rapidly upregulated in T2D and its overexpression causes substantial obesity in mice. ${ }^{74}$ Another condition that has the potential to be treated is short bowel syndrome, for which the GLP-2 receptor agonist, teduglutide, has been successfully trialled. ${ }^{75}$ An aim of GLP-2 agonism is to facilitate mucosal repair and growth and reduce dependence on parenteral nutrition.

\section{Sensory neurons}

\section{Extrinsic sensory neurons}

Both extrinsic and intrinsic neural pathways carry gastrointestinal sensory information. The first neurons in the sensory pathways are commonly referred to as primary afferent neurons because only a small proportion are sensory neurons in the strict sense of their activation leading to conscious sensation. ${ }^{76}$ Here, we use afferent and sensory interchangeably. The four extrinsic sensory pathways are the vagal (with first order cell bodies in nodose and jugular ganglia), thoracolumbar (first order cell bodies in thoracolumbar dorsal root ganglia, DRG), lumbosacral (first order cell bodies in lumbosacral DRG) and the viscerofugal pathways (first order neurons in the gut wall). ${ }^{33,77}$

\section{Vagal, thoracolumbar and lumbosacral}

Vagal, thoracolumbar and lumbosacral sensory neurons give rise to endings in the gut wall that respond to both chemical and mechanical stimuli. A review published in 2013 proposed that extrinsic sensory neurons can be categorized, by the arrangements and morphologies of their nerve endings, into five subgroups: neurons with intraganglionic laminar endings (IGLEs), mucosal afferents, muscular-mucosal afferents, intramuscular arrays (IMAs), and vascular afferents. ${ }^{77}$ Sensory endings in the mucosal lamina propria (mucosal afferents) do not penetrate the epithelium, and they sense nutrients indirectly via signals that are released from the epithelium, primarily from enteroendocrine cells. $^{78}$

Vagal sensory nerve endings have receptors for hormones released from enteroendocrine cells, including receptors for CCK, ${ }^{47}$ GLP-1 and GLP-2, ${ }^{79} 5-\mathrm{HT},{ }^{80}$ ghrelin ${ }^{81,82}$ and PYY. ${ }^{45}$ The effect of PYY on the vagus is probably indirect, through the release of CCK. ${ }^{31,47}$ The activation of sensory nerve endings includes activation by nutrients, for example, fats release CCK that acts on mucosal afferent endings in the small intestine, ${ }^{31}$ and non-nutrient chemicals, such as bitter-tasting chemicals. ${ }^{83}$ The existence of $>30$ bitter taste receptors possibly permits detection of a wide range of chemical entities as being bitter. Vagal mucosal afferents are not sensitive to distension, but can be activated by mucosal stroking. ${ }^{77}$

Bacterial products activate vagal afferents; the probiotic bacterium Lactobacillus rhamnosus increased spontaneous vagal afferent firing rate and augmented vagal afferent discharge in response to intralumenal distension. ${ }^{84}$ The mechanisms of vagal activation by bacteria or bacterial products are 
unknown. They could interact directly with TLRs expressed by afferent neurons ${ }^{85}$ and/or the afferents could be activated indirectly through stimulation of enteroendocrine cells by bacterial products.

IGLEs and IMAs are mechanoreceptor endings that are found in the external layers of the gastrointestinal tract. IGLEs arise from both vagal and lumbosacral afferents and are located in close proximity to enteric ganglia, between the circular and longitudinal muscle layers of the oesophagus, stomach, small and large intestines ${ }^{86,87}$ They have low mechanical thresholds for activation and are sensitive to distension or direct application of pressure to the endings. ${ }^{88,89}$ IGLEs of vagal origin are mainly found in the oesophagus and the stomach, whereas IGLEs of lumbosacral origin are found in the colon and rectum. IMAs are located within the circular smooth muscle layers and form synapselike complexes with interstitial cells of Cajal (ICC). ${ }^{90}$ Powley et al. ${ }^{90}$ have postulated that IMAs, ICC and smooth muscle work cooperatively or synergistically to transduce specific stretch or muscle length information. Muscular-mucosal afferents respond to both stretch and mucosal stroking. ${ }^{91}$

Arteries throughout the body have a dense sensory innervation from unmyelinated $C$ fibre afferents, with particularly high densities observed in vessels that supply the gut, including small arteries within the gut wall. ${ }^{92}$ The fibres arise from DRG and their sensory endings around the mesenteric arteries close to the gut are mechanosensitive. ${ }^{77}$ Neurogenic inflammation, which seems to be mediated by the peptide calcitonin gene-related peptide released from the vascular afferents, has an important mucosal protective role in the gastrointestinal tract, especially in the stomach. ${ }^{93}$

Many extrinsic afferent neurons that innervate the gut, termed silent nociceptors, are mechanically insensitive in conditions of normal health, but can be activated by mechanical forces in the physiological range when the tissue is inflamed, and these afferents can remain excitable, even when a severe inflammation has subsided. ${ }^{94}$ Evidence now indicates that muscular-mucosal afferents and vascular afferents, but not muscle afferents, become sensitized and acquire mechanosensitivity following inflammation. . $^{77,95}$

Vagal afferents carry information of the physiological state of the digestive $\operatorname{tract}^{77}$ (discussed above). By contrast, it is an old observation that severing the sympathetic pathways (which are followed by axons of thoracolumbar afferent neurons) prevents abdominal visceral pain, implying that most pain and discomfort of gastrointestinal origin is conveyed by these afferent neurons. ${ }^{96,97}$

Intestinofugal

Intestinofugal neurons (Figure 3) are an unusual type of neuron, peculiar to the gastrointestinal tract, that have cell bodies in the gut wall and send their processes to prevertebral ganglia (where they form synapses with postganglionic sympathetic neurons), other digestive organs and the CNS. ${ }^{98}$ Intestinofugal neurons that project to sympathetic ganglia are within the afferent limbs of nerve pathways of entero-enteric reflexes, that is, reflexes that are initiated from the intestine, and then act back on the stomach or intestine. ${ }^{33,99}$ The sensory stimuli that activate these pathways include distension, acid in the proximal small intestine and fats in the distal small intestine. The sympathetic neurons that are innervated by intestinofugal neurons inhibit motility and fluid secretion. The effect of inhibiting motility in the stomach and proximal small intestine is to slow transit of contents (discussed earlier). Gastric inhibition is also likely to involve hormonal effects on the stomach mediated by GLP-1 and PYY, ${ }^{43}$ and possibly also GIP ${ }^{100}$ and oxyntomodulin. ${ }^{101}$

Intrinsic sensory neurons

Although neural reflexes were found to influence movement and secretion in the isolated intestine $>100$ years ago, it was not until the 1990s that intrinsic sensory neurons were identified. ${ }^{102,103}$ These large multipolar neurons - commonly referred to as IPANs (intrinsic primary afferent neurons) — have characteristic electrophysiological properties, notably substantial after hyperpolarizing potentials that follow their action potentials and limit their firing rates. ${ }^{104}$ IPANs detect distortion of the mucosa, chemical changes in the lumen, tension changes in the muscle and compressive forces on enteric ganglia. Neurons in other parts of nerve circuits within the gut wall, including interneurons and motor neurons, can also respond directly to mechanical stimulation. ${ }^{105-107}$ A remaining challenge is to determine the relationship between IPAN activation and mechanical activation of other neurons of the enteric nervous system (ENS) in the generation or modulation of enteric reflexes.

Clinical implications

Receptors on extrinsic sensory neurons have been proposed as targets to reduce visceral pain, with a 
particular focus on IBS-related pain because of the common nature of this condition. However, despite many targets being tested, including TRP receptors, tachykinin receptors and 5-HT receptors, no satisfactory pharmacological treatment has emerged. ${ }^{108,109}$ The potential to target sensory neurons to modify physiological regulation of digestive function is under-researched. However, glutamate receptor antagonists could limit transient relaxations of the lower oesophageal sphincter associated with gastric reflux disease. ${ }^{110}$ Glutamate receptor antagonists reduce the excitability of the sensory nerve endings of vagal afferents through which vago-vagal reflex relaxation is initiated. However, these studies have not yet led to the introduction of treatments. Vagal sensory neurons could be feasibly targeted to modify feeding and satiety, ${ }^{111}$ but, other than ghrelin agonists, no therapies based on this hypothesis have yet emerged. In humans, the principal actions of ghrelin receptor agonists to increase food intake is on vagal nerve endings. ${ }^{82}$ The ghrelin receptor agonist, anamorelin, is effective in cachexia, ${ }^{112}$ but it releases insulin-like growth factor which has potential diabetogenic effects. Therapies based on targeting intrinsic sensory neurons have not yet emerged.

\section{Immune defence}

Bacteria: good and bad

The mammalian gut, and the intestines of other vertebrates and invertebrates, contain vast numbers of bacteria. ${ }^{113}$ Bacterial symbionts metabolize food components (such as plant carbohydrates, including pectins and celluloses, which would otherwise not provide host nutrition), maintain epithelial integrity, defend against pathogenic bacteria and promote development and maturation of the mucosa., ${ }^{3,14,115}$ Pathogenic bacteria and the toxins they release compromise host immune responses; they precipitate various inflammatory disorders and specific disease entities. ${ }^{115}$ Examples of pathobionts include Helicobacter pylori and pathogenic strains of Escherichia coli. The gut both senses its bacterial load and interacts with the microbiome to shape its own ecosystem. ${ }^{116}$

Roles of bacteria in maturation of the gut are emphasized by studies of mice reared under gnotobiotic or germ-free conditions. In germ-free mice, Peyer's patches lack germinal centre formation, isolated lymphoid follicles do not form, the composition of $\mathrm{CD}^{+} \mathrm{T}$ cells and IgAproducing $\mathrm{B}$ cells in the lamina propria is altered and mucosa-associated invariant $\mathrm{T}$ cells (MAIT cells) are deficient when compared with conventionally housed animals. ${ }^{3,117}$ Provision of bacteria, or bacterial products, to germ-free mice restores the mucosal immune system. ${ }^{118,119}$ Of note, germ-free mice to which normal gut microbiota are introduced in adulthood have increased carbohydrate uptake and $60 \%$ more fat deposition compared with animals that remain germ free, despite mice with introduced microbiota consuming less food. ${ }^{120}$

\section{Detection of bacterial antigens}

Gastrointestinal mucosal T cells have three locations: lymphoid aggregations termed Peyer's patches and numerous small lymphoid follicles; as individual cells scattered in the connective tissue beneath the mucosal epithelium; and as intraepithelial lymphocytes (IELs), mostly $\mathrm{CD}^{+} \mathrm{T}$ cells, within the epithelial layer. Numerous amongst mucosal $\mathrm{T}$ cells are conventional $\mathrm{CD} 4^{+}$and $\mathrm{CD}^{+}$cells whose surface repertoire of antigen receptors bind to peptide fragments from proteins. In addition, in the mucosa, natural killer T cells recognise lipid molecules presented by dendritic cells. A new discovery is that MAIT cells, which have a limited repertoire of antigen receptors, detect and are activated by metabolites of bacterial vitamin B2 (riboflavin) and B9 (folic acid). ${ }^{124}$ MAIT cells have been found mostly in the intestine, liver and lung. ${ }^{117}$ This discovery in 2012 was the first suggestion that vitamins can act as antigens. ${ }^{125}$ Vitamin B biosynthetic pathways are present in bacteria and yeast, and MAIT cells have been suggested to use metabolites from these organisms to detect microbial infection. ${ }^{124}$ As the metabolites are secreted and can diffuse across the mucosal epithelial barrier, MAIT cells within the lamina propria presumably detect bacteria in the lumen. Moreover, as abundant resident mucosal cells, MAIT cells have the potential to control microorganisms in the early phases of microbial infection. ${ }^{126}$ The absence of MAIT cells in germ-free mice ${ }^{117}$ suggests that their development depends on the presence of bacterial products. Protection against pathogens by MAIT cells could be augmented by provision of vitamins in the diet or by pterin-based therapies. ${ }^{125}$ Augmentation could enhance immunity to microbes, and might even aid in treating immunodeficiencies. ${ }^{125}$

Local defence against microorganisms

Bacterial antigens are recognised by pattern-recognition receptors, primarily TLRs and nucleotide- 
binding oligomerization domain (NOD) receptors, that bind conserved structures of bacteria, viruses, fungi and certain parasites. ${ }^{127}$ TLRs 1-9 and NOD1 and NOD2 are expressed by intestinal epithelial cells. $^{2}$

In response to TLR and NOD activation, the release of antimicrobial defence molecules (ADMs), which includes antimicrobial peptides and lectins, provides an initial defence against pathogenic bacteria. ${ }^{128,129}$ The major source of ADMs in the small intestine is Paneth cells, but ADMs are also released from intestinal epithelial cells and by neutrophils in the intestine, as in other organs. Paneth cells express NOD2 and several TLRs, including TLR2, 4, 5, and 9. ${ }^{130}$ The major classes of ADMs in the intestine are: defensins, small $(2-6 \mathrm{kDa})$ cationic peptides that kill bacteria primarily by disruption of cell walls; lysozyme $\mathrm{C}$, which hydrolizes bacterial peptidoglycans, thus restricting their proinflammatory effects; phospolipases, including PLA2, some of which have preferential activity at bacterial membranes; bacteriocidal lectins, the main lectins of human Paneth cells being REG3 $\alpha$ and

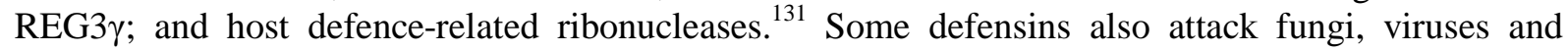
protozoa. Paneth cells also produce a range of inflammatory mediators, which includes IL-17A, TNF, IL-1B and lipokines. ${ }^{129}$

The adaptor molecule, MyD88, is downstream from NOD2, and manipulation of Myd88 in mice revealed that Paneth cell ADMs limit bacterial numbers in the mucous layer at the mucosal surface, and consequently the translocation of bacteria to mesenteric lymph nodes. ${ }^{130}$ NOD2 is present predominantly, although not exclusively, in Paneth cells in the small intestine and mutations of this protein are commonly associated with Crohn's disease; ${ }^{132}$ targeting enhancement of Paneth cell function could therefore be useful in treating IBD. It is feasible that positive effects of GLP-2 receptor agonists in $\mathrm{IBD}^{133}$ are due, in part, to their actions on Paneth cells, ${ }^{56}$ but further investigation is required.

\section{Nonimmune defence mechanisms}

\section{Noxious chemicals and pharmaceuticals}

The gut has mechanisms to detect noxious chemicals, for example those that occur in plants, toxic products of bacteria and products of putrefaction. The smell, taste and association of potentially toxic substances with nausea elicit aversive behaviours, so that the substances are avoided. Potentially toxic chemicals initiate expulsion, by vomiting and diarrhoea; chemicals are detoxified through recognition by transporters and metabolism by detoxifying enzymes. Pharmaceutical compounds, although not present in the period of evolution of toxin sensing, are detoxified via the same pathways. The initial sensing of toxins is through olfaction and taste, notably by odorant receptors and bitter taste receptors in the nose and oral cavity. Recognition continues after food is swallowed, for example, administration of bitter compounds into the stomach activates second order neurons in the brain stem, ${ }^{83}$ through a signalling pathway that might be related to emesis.

Mechanisms to recognise and detoxify chemicals

Foreign compounds that reach the intestine are recognised by specific foreign compound transporters, including the peptide transporter family, ${ }^{134}$ oligopeptide transporters ${ }^{135}$ and organic anion transporters. ${ }^{136}$ Oligopeptides without toxicity are also recognised by peptide transporter families, including incompletely digested nutrient proteins. After they are transported across the epithelium, compounds are exposed to a range of detoxifying enzymes in the wall of the intestine, some of the enzymes being expressed by enterocytes themselves. ${ }^{137}$ Detoxifying enzymes in the intestine include cytochromes P450, uridine diphosphate glucuronosyltransferases, sulphotransferases, acetyltransferases, glutathione S-transferases, esterases, epoxide hydrolase and alcohol dehydrogenase. ${ }^{137}$ This is the first line of defence; those chemicals that escape into the portal venous drainage are exposed to a similar range of detoxifying enzymes in the liver.

\section{Receptors for advanced glycation end products}

Other compounds that are ingested and have adverse effects are advanced glycation end products (AGEs). AGEs are formed by nonenzymatic attachment of reducing sugars to the amino groups of proteins through a series of intermediary reactions, which can occur when foods are overheated (for example, by deep frying) and in hyperglycaemic conditions. AGEs are reported to contribute to the development of diabetes. ${ }^{138}$ Receptors for AGEs (RAGEs) are present in the epithelial lining of the small intestine, in the villi and the crypts, and on enteric neurons. ${ }^{139}$ These receptors bind AGEs and a 
range of other ligands, to initiate proinflammatory cascades. ${ }^{140}$ RAGE-dependent inflammation might contribute to AGE-induced damage to enteric neurons. ${ }^{141}$ The most effective ways to deal with the harmful effects of AGEs are public health and education measures to reduce the intake of foods that are exposed to high temperatures, especially high temperatures in the presence of excess sugars, during their preparation.

Eliminating toxins

Emesis is initiated by toxins or irritants in the gastrointestinal tract, by toxins that cross into the circulation and reach the vomiting centres in the area postrema, by nausea induced by smell and by vestibular disturbance (motion sickness). The gastrointestinal component is dependent on the release of 5-HT from enteroendocrine cells, which acts on vagal nerve endings in the gut wall to transmit the signal to vomiting centres in the brain. ${ }^{80}$ Antagonists of $5-\mathrm{HT}_{3}$ receptors are effective antiemetics. The presence of large amounts of 5-HT in the enteroendocrine cells of the stomach and duodenum is thought to provide a defence against toxic substances. ${ }^{142}$ Indeed, these cells do act as detectors of emetogenic toxins and of hypertonic salt solutions that are effective initiators of vomiting. Of note, 5 -HT-containing enteroendocrine cells express $\mathrm{TLRs}^{58}{ }^{58}$ and are thus predicted to be activated by bacterial antigens.

The initiation of strong rapidly moving, nerve-mediated propulsive contractions, in both the small and large intestines, assists in ridding the gut of undesired contents. These propulsive contractions are evoked by pathogens and their products, including parasitic nematodes, the bacterial pathogen, Vibrio cholera, and bacterial toxins, as well as by irritants, such as ricinoleic acid, the active component of castor oil. ${ }^{33}$ Although it has not been proven, these expulsive movements might be initiated by 5-HT, which is an effective stimulant of propulsion, and which activates the sensory endings of IPANs. ${ }^{143,144}$ IPANs are also activated in food allergy. ${ }^{145}$

Pathogens and their products, including cholera toxin, enterotoxins and rotavirus, are sensed by enteric neurons in secretomotor reflex pathways, ${ }^{33,146}$ triggering copious watery diarrhoea, which along with the stimulation of propulsion, expels toxins and pathogens. The pathways can be overstimulated and infectious diarrhoea, if unchecked, can cause death through water and electrolyte loss. ${ }^{147}$

\section{Integration and intercommunication}

One of the prominent features of the digestive tract is the close integration of its responses to luminal contents, which includes interactions of the enteroendocrine, neural and tissue defence systems. This integration can be illustrated at the level of a single cell type, the L cell, and, at the level of function, the integrated response to a meal. Extensive interactions occur between neurons and the immune system of the gastrointestinal tract, a field that is reviewed elsewhere. ${ }^{148-150}$

Sensing and responding through the $L$ cell

We have used the $\mathrm{L}$ cell as a focus to exemplify the interactions between sensory inputs and the four effector systems. Although this example is one for which there are good experimental data, many details remain to be clarified. L cells (Figure 3) have luminal receptors for fats, carbohydrates, protein metabolites and bile salts, ${ }^{4,14,151}$ although the relative roles of these receptors in control of $\mathrm{L}$ cell hormone release are not yet determined and it is not known whether the bile acid receptors on L cells have a physiological role. L cells release GLP-2, one of whose targets is enteric neurons. ${ }^{52,152}$ Neurons activated by GLP-2 increase glucose uptake through SGLT1 ${ }^{23}$ VIP neurons that are activated by GLP-2 return fluid to the lumen by stimulating chloride and coupled water secretion. ${ }^{98}$ GLP-2 from $\mathrm{L}$ cells also enhances mucosal growth and repair, increases amino acid and fat absorption, increases activities of digestive enzymes, enhances intestinal barrier function ${ }^{21,22,55}$ and has anti-inflammatory effects. ${ }^{51,53}$ Because of these actions, GLP-2 receptor agonists have potential in the treatment of short bowel syndrome and IBD. ${ }^{75,133}$ GLP-1 has important functions as an incretin, a satiety factor, an inhibitor of gastric emptying and an inhibitor of gastric acid secretion. PYY released from L cells in response to fat is a key element of the ileal brake that restricts the rate of intestinal transit when undigested fats are present in the distal small intestine. ${ }^{33,42}$ PYY also reduces water and electrolyte secretion, primarily by acting to inhibit enteric secretomotor neurons, but also by acting on the enterocytes $^{153,154}$ and is a satiety factor. The other major hormone released from L cells, oxyntomodulin, whose action is mediated through GLP-1 and glucagon receptors, has satiating effects when artificially administered, but whether endogenous oxyntomodulin contributes to satiety is 
uncertain. ${ }^{101,155}$ Activation of a vago-vagal reflex and local nerve stimulation can both enhance hormone secretion from L cells. ${ }^{156,157}$

The integrated response to a meal

The sight, smell or even the thought of food prepares the digestive tract, by increasing salivary and gastric acid secretion and relaxing the stomach wall. The arrival of the food in the stomach stimulates mechanoreceptors, acid receptors, protein (peptone) receptors, bitter taste receptors and probably other receptors. As a consequence, gastric volume increases, mixing contractions are initiated, mucosal blood flow is enhanced, acid and proteases are released, and mucosal defences against autodigestion are marshalled. If potentially toxic contaminants are ingested, nausea and vomiting might be induced. The gastric response thus requires integration of the responses of a range of receptors and engagement of hormonal, neural and tissue protective responses. In the small intestine, the nutrient content, acidity, osmolarity, bacterial load, noxious chemicals and amount of material arriving from the stomach are amongst the properties sensed. The outcomes include adjustment of mixing and propulsive activity, altered water and electrolyte exchange across the lining epithelium, increased mucosal blood flow, secretion of neutralising bicarbonate, secretion of digestive enzymes, activation of nutrient transporters, insulin secretion, entry of bile acids, release of antimicrobials from Paneth cells and presentation of bacterial and other antigens to $\mathrm{T}$ cells resident in the intestine. The integrated responses optimize nutrient assimilation and organ protection.

\section{Conclusions}

The sensing mechanisms of the gut and the effector systems with which they communicate are in intimate anatomical and functional relationships. The lining of the gastrointestinal tract has a comprehensive range of sensory receptors, including nutrient receptors, odorant receptors, patternrecognition receptors, toxin and other foreign chemical receptors and mechanoreceptors. These receptors feed into hormonal, neural, immune and tissue defence systems. Evidence of close interaction is very clear. A future challenge is to integrate findings obtained in studies that, of necessity, have focused on particular disciplines (for example in immunology, endocrinology, neurogastroenterology, nutrition, gut bacteriology and the gut-brain axis) to provide a comprehensive understanding of how the sensory mechanisms of the gastrointestinal tract collectively relate to digestive physiology and pathology. Another challenge is to take advantage of growing knowledge of luminal receptor pharmacology and physiology to develop novel therapeutic agents.

\section{Review criteria}

Literature searches have concentrated on publications in the past 10 years. Earlier publications have been sought out by reference back from contemporary work. Combinations of the following search terms were used: "intestine", "gastrointestinal", "gut hormone", "enteroendocrine", "immune system", "enteric nervous system", "taste receptor", "gut afferent" and "microbiota". Searches were conducted using Google Scholar and PubMed. Additional insights have been gained by consultation with colleagues (see also acknowledgements).

1. Ferraris, R. P., Lee, P. P. \& Diamond, J. M. Origin of regional and species differences in intestinal glucose uptake. Am. J. Physiol. 257, G689-G697 (1989).

2. MacDonald, T. T. \& Monteleone, G. Immunity, inflammation, and allergy in the gut. Science 307, 1920-1925 (2005).

3. Artis, D. Epithelial-cell recognition of commensal bacteria and maintenance of immune homeostasis in the gut. Nat. Rev. Immunol. 8, 411-420 (2008).

4. Engelstoft, M. S., Egerod, K. L., Holst, B. \& Schwartz, T. W. A gut feeling for obesity: 7TM sensors on enteroendocrine cells. Cell Metab. 8, 447-449 (2008).

5. Rehfeld, J. F. A centenary of gastrointestinal endocrinology. Horm. Metab. Res. 36, 735-741 (2004).

6. Janssen, S. \& Depoortere, I. Nutrient sensing in the gut: new roads to therapeutics? Trends Endocrinol. Metab. 24, 92-100 (2013).

7. $\mathrm{Wu}, \mathrm{S}$. V. et al. Expression of bitter taste receptors of the $\mathrm{T} 2 \mathrm{R}$ family in the gastrointestinal tract and enteroendocrine STC-1 cells. Proc. Natl Acad. Sci. USA 99, 2392-2397 (2002).

8. Rozengurt, E. \& Sternini, C. Taste receptor signaling in the mammalian gut. Curr. Opin. Pharm. 7, 557-562 (2007).

9. Young, R. L. Sensing via intestinal sweet taste pathways. Front. Neurosci. 5, 1-13 (2011).

10. Sutherland, K., Young, R. L., Cooper, N. J., Horowitz, M. \& Blackshaw, L. A. Phenotypic characterization of taste cells of the mouse small intestine. Am. J. Physiol. 292, G1420-G1428 (2007).

11. Huang, A. L. et al. The cells and logic for mammalian sour taste detection. Nature 442, 934-938 (2006).

12. Chaudhari, N. \& Roper, S. D. The cell biology of taste. J. Cell Biol. 190, 285-296 (2010).

13. Margolskee, R. F. et al. T1R3 and gustducin in gut sense sugars to regulate expression of $\mathrm{Na}^{+}$-glucose cotransporter 1. Proc. Natl Acad. Sci. USA 104, 15075-15080 (2007). 
14. Geraedts, M. C. P. et al. Transformation of postingestive glucose responses after deletion of sweet taste receptor subunits or gastric bypass surgery. Am. J. Physiol. 303, E464-E474 (2012).

15. Brown, R. J., Walter, M. \& Rother, K. I. Ingestion of diet soda before a glucose load augments glucagon-like peptide-1 secretion. Diabetes Care 32, 2184-2186 (2009).

16. Gerspach, A. C., Steinert, R. E., Schönenberger, L., Graber-Maier, A. \& Beglinger, C. The role of the gut sweet taste receptor in regulating GLP-1, PYY, and CCK release in humans. Am. J. Physiol. 301, E317-E325 (2011).

17. Drucker, D. J. \& Nauck, M. A. The incretin system: glucagon-like peptide-1 receptor agonists and dipeptidyl peptidase-4 inhibitors in type 2 diabetes. Lancet 368, 1696-1705 (2006).

18. Reimann, F. et al. Glucose sensing in L cells: a primary cell study. Cell Metab. 8, 532-539 (2008).

19. Gorboulev, V. et al. Na ${ }^{+}-\mathrm{D}$-glucose cotransporter SGLT1 is pivotal for intestinal glucose absorption and glucose-dependent incretin secretion. Diabetes 61, 187-196 (2012).

20. Diakogiannaki, E., Gribble, F. \& Reimann, F. Nutrient detection by incretin hormone secreting cells. Physiol. Behav. 106, 387-393 (2012).

21. Brubaker, P. L., Izzo, A. A., Hill, M. \& Drucker, D. J. Intestinal function in mice with small bowel growth induced by glucagon-like peptide-2. Am. J. Physiol. 272, E1050-E1058 (1997).

22. Hsieh, J. et al. Glucagon-like peptide-2 increase intestinal lipid absorption and chylomicron production via CD36. Gastroenterology 137, 997-1005 (2009).

23. Shirazi-Beechey, S. P., Moran, A. W., Batchelor, D. J., Daly, K. \& Al-Rammahi, M. Influences of food constituents on gut health glucose sensing and signalling; regulation of intestinal glucose transport. Proc. Nutr. Soc. 70, 185-193 (2011)

24. Iwatsuki, K. et al. Detecting sweet and umami tastes in the gastrointestinal tract. Acta Physiol. 204, 169-177 (2012)

25. Hass, N., Schwarzenbacher, K. \& Breer, H. T1R3 is expressed in brush cells and ghrelin-producing cells of murine stomach. Cell Tissue Res. 339, 493-504 (2010).

26. Iwatsuki, K. \& Uneyama, H. Sense of taste in the gastrointestinal tract. J. Pharmacol. Sci. 118, 123-128 (2012).

27. Daly, K. et al. Sensing of amino acids by the gut-expressed taste receptor T1R1-T1R3 stimulates CCK secretion. Am. J. Physiol. Gastrointest. Liver Physiol. 304, G271-G282 (2013).

28. Janssen, S. et al. Bitter taste receptors and $\alpha$-gustducin regulate the secretion of ghrelin with functional effects on food intake and gastric emptying. Proc. Natl Acad. Sci. USA 108, 2094-2099 (2011).

29. Hunt, J. N. \& Stubbs, D. F. The volume and energy content of meals as determinants of gastric emptying. J. Physiol. 245, 209-225 (1975).

30. Edfalk, S., Steneberg, P. \& Edlund, H. Gpr40 is expressed in enteroendocrine cells and mediates free fatty acid stimulation of incretin secretion. Diabetes 57, 2280-2287 (2008).

31. Strader, A. D. \& Woods, S. C. Gastrointestinal hormones and food intake. Gastroenterology 128, 175-191 (2005).

32. Mawe, G. M. Nerves and hormones interact to control gallbladder function. News Physiol. Sci. 13, 84-90 (1998).

33. Furness, J. B. The Enteric Nervous System (Blackwell, Oxford, 2006).

34. Wang, Y. et al. Amino acids stimulate cholecystokinin release through the $\mathrm{Ca}^{+}{ }^{+}$-sensing receptor. Am. J. Physiol. Gastrointest. Liver Physiol. 300, G528-G537 (2011).

35. Little, T. J. et al. The release of GLP-1 and ghrelin, but not GIP and CCK, by glucose is dependent upon the length of small intestine exposed. Am. J. Physiol. 291, E647-E655 (2006).

36. Xiong, Y. et al. Activation of FFA1 mediates GLP-1 secretion in mice. Evidence for allosterism at FFA1. Mol. Cell. Endocrinol. 369, 119-129 (2013).

37. Poreba, M. A. et al. Role of fatty acid transport protein 4 in oleic acid-induced glucagon-like peptide-1 secretion from murine intestinal L cells. Am. J. Physiol. Endocrinol. Metab. 303, E899-E807 (2012).

38. Tolhurst, G., Reimann, F. \& Gribble, F. M. in Appetite control, Handbook of Experimental Pharmacology (ed. Joost, H.-G.) 309-335 (Springer-Verlag, Berlin, Heidelberg, 2012).

39. Karaki, S.-I. et al. Short-chain fatty acid receptor, GPR43, is expressed by enteroendocrine cells and mucosal mast cells in rat intestine. Cell Tissue Res. 324, 353-360 (2006).

40. Chu, Z. L. et al. A role of intestinal endocrine cell-expressed G protein-coupled receptor 119 in glycemic control by enhancing glucagon-like peptide-1 and glucose-dependent insulinotropic peptide release. Endocrinology 149, 2038-2047 (2008).

41. Cox, H. M. et al. Peptide YY is critical for acylethanolamine receptor Gpr119-induced activation of gastrointestinal mucosal responses. Cell Metab. 11, 532-542 (2010).

42. Lin, H. C., Zhao, X.-T., Wang, L. \& Wong, H. Fat-induced ileal brake in the dog depends on peptide YY. Gastroenterology 110, 1491-1495 (1996).

43. Holst, J. J. The physiology of glucagon-like peptide 1. Physiol. Rev. 87, 1409-1439 (2007).

44. Chaudhri, O. B., Field, B. C. T. \& Bloom, S. R. Gastrointestinal satiety signals. Int. J. Obesity 32, S28-S31 (2008).

45. Abbott, C. R. et al. The inhibitory effects of peripheral administration of peptide YY3-36 and glucagon-like peptide- 1 on food intake are attenuated by ablation of the vagal-brainstem-hypothalamic pathway. Brain Res. 1044, 127-131 (2005).

46. Ogawa, N. et al. Intestinal fatty acid infusion modulates food preference as well as calorie intake via the vagal nerve and mid-brain-hypothalamic neural pathways in rats. Metabolism 61, 1312-1320 (2012).

47. Raybould, H. E. Mechanisms of CCK signaling from gut to brain. Curr. Opin. Pharm. 7, 570-574 (2007). 
48. Cordier-Bussat, M. et al. Peptones stimulate both the secretion of the incretin hormone glucagon-like peptide 1 and the transcription of the proglucagon gene. Diabetes 47, 1038-1045 (1998).

49. Haid, D., Jordan-Biegger, C., Widmayer, P. \& Breer, H. Receptors responsive to protein breakdown products in G-cells and D-cells of mouse, swine and human. Front. Physiol. 3, 1-15 (2012).

50. Haid, D., Widmayer, P. \& Breer, H. Nutrient sensing receptors in gastic endocrine cells. J. Mol. Hist. 42, 355364 (2011).

51. Drucker, D. J., Ehrlich, P., Asa, S. L. \& Brubaker, P. L. Induction of intestinal epithelial proliferation by glucagon-like peptide 2. Proc. Natl Acad. Sci. USA 93, 7911-7916 (1996).

52. Sigalet, D. L. et al. Enteric neural pathways mediate the anti-inflammatory actions of glucagon-like peptide 2. Am. J. Physiol. 293, G211-G221 (2007).

53. Rowland, K. J. \& Brubaker, P. L. The "cryptic" mechanism of action of glucagon-like peptide-2. Am. J. Physiol. 301, G1-G8 (2011).

54. Yusta, B., Holland, D., Waschek, J. A. \& Drucker, D. J. Intestinotrophic glucagon-like peptide-2 (GLP-2) activates intestinal gene expression and growth factor-dependent pathways independent of the vasoactive intestinal peptide gene in mice. Endocrinology 153, 2623-2632 (2012).

55. Cani, P. D. et al. Changes in gut microbiota control inflammation in obese mice through a mechanism involving GLP-2-driven improvement of gut permeability. Gut 58, 1091-1103 (2009).

56. Lee, S.-J. et al. Disruption of the murine Glp2r impairs paneth cell function and increases susceptibility to small bowel enteritis. Endocrinology 153, 1141-1151 (2012).

57. Bremholm, L., Hornum, M., Henriksen, B. M., Larsen, S. \& Holst, J. J. Glucagon-like peptide-2 increases mesenteric blood flow in humans. Scand. J. Gastroenterol. 44, 314-319 (2009).

58. Bogunovic, M. et al. Enteroendocrine cells express functional toll-like receptors. Am. J. Physiol. Gastrointest. Liver Physiol. 292, G1770-G1783 (2007).

59. Palazzo, M. et al. Activation of enteroendocrine cells via TLRs induces hormone, chemokine and defensin secretion. J. Immunol. 178, 4296-4303 (2007).

60. Selleri, S. et al. Induction of pro-inflammatory programs in enteroendocrine cells by the toll-like receptor agonists flagellin and bacterial LPS. Int. Immunol. 20, 961-970 (2008).

61. Holzer, P. TRP channels in the digestive system. Curr. Pharm. Biotechnol. 12, 24-34 (2011).

62. Breer, H., Eberle, J., Frick, C., Haid, D. \& Widmayer, P. Gastrointestinal chemosensation: chemosensory cells in the alimentary tract. Histochem. Cell Biol. 138, 13-24 (2012).

63. Franz, C., Baser, K. H. C. \& Windisch, W. Essential oils and aromatic plants in animal feeding-A European perspective. Flavour Fragr. J. 25, 327-340 (2010).

64. Venkatachalam, K. \& Montell, C. TRP channels. Annu. Rev. Biochem. 76, 387-417 (2007).

65. Purhonen, A. K., Louhivuori, L. M., Kiehne, K., Akerman, K. E. O. \& Herzig, K. H. TRPA1 channel activation induces cholecystokinin release via extracellular calcium. FEBS Lett. 582, 229-232 (2008).

66. Nozawa, K. et al. TRPA1 regulates gastrointestinal motility through serotonin release from enterochromaffin cells. Proc. Natl. Acad. Sci. USA 106, 3408-3413 (2009).

67. Liman, E. R. TRPM5 and taste transduction. Handb. Exp. Pharmacol. 179, 286-296 (2007).

68. Damak, S. et al. Trpm5 null mice respond to bitter, sweet, and umami compounds. Chem. Senses 31, 253-264 (2006).

69. Braun, T., Voland, P., Kunz, L., Prinz, C. \& Gratzl, M. Enterochromaffin cells of the human gut: sensors for spices and odorants. Gastroenterology 132, 1890-1901 (2007).

70. Kaji, I., Karaki, S.-I. \& Kuwahara, A. Effects of luminal thymol on epithelial transport in human and rat colon. Am. J. Physiol. 300, G1132-G1143 (2011).

71. Russell-Jones, D. et al. Efficacy and safety of exenatide once weekly versus metformin, pioglitazone, and sitagliptin used as monotherapy in drug-naive patients with type 2 diabetes (Duration-4). Diabetes Care 35, 252-258 (2012).

72. Katz, L. B. et al. Effects of JNJ-38431055, a novel GPR119 receptor agonist, in randomized, double-blind, placebo-controlled studies in subjects with type 2 diabetes. Diabetes Obes. Metab. 14, 709-716 (2012).

73. Stearns, A. T., Balakrishnan, A., Rhoads, D. B. \& Tavakkolizadeh, A. Rapid upregulation of sodiumglucosetransporter SGLT1 in response to intestinal sweet taste stimulation. Ann. Surg. 251, 865-871 (2010).

74. Osswald, C. et al. Mice without the regulator gene Rsc1A1 exhibit increased $\mathrm{Na}^{+}-D$-Glucose cotransport in small intestine and develop obesity. Mol. Cell. Biol. 25, 78-87 (2005).

75. Jeppsesen, P. B. et al. Randomised placebo-controlled trial of teduglutide in reducing parenteral nutrition and/or intravenous fluid requirements in patients with short bowel syndrome. Gut 60, 902-914 (2011).

76. Cervero, F. Sensory innervation of the viscera: Peripheral basis of visceral pain. Physiol. Rev. 74, 95-138 (1994)

77. Brookes, S. J. H., Spencer, N. J., Costa, M. \& Zagorodnyuk, V. P. Extrinsic primary afferent signalling in the gut. Nat. Rev. Gastroenterol. Hepatol. 10, 286-296 (2013).

78. Berthoud, H. R., Kressel, M., Raybould, H. E. \& Neuhuber, W. L. Vagal sensors in the rat duodenal mucosa: distribution and structure as revealed by in vivo Dil tracing. Anat. Embryol. 191, 203-212 (1995).

79. Bucinskaite, V. et al. Receptor-mediated activation of gastric vagal afferents by glucagon-like peptide-1 in the rat. Neurogastroenterol. Motil. 21, 978-e78 (2009).

80. Andrews, P. L. R. et al. The abdominal visceral innervation and the emetic reflex: pathways, pharmacology, and plasticity. Can. J. Physiol. Pharmacol. 68, 325-345 (1990).

81. Date, Y. et al. The role of the gastric afferent vagal nerve in ghrelin-induced feeding and growth hormone 
secretion in rats. Gastroenterology 123, 1120-1128 (2002).

82. le Roux, C. W. et al. Ghrelin does not stimulate food intake in patients with surgical procedures involving vagotomy. J. Clin. Endocrinol. Metab. 90, 4521-4524 (2005).

83. Hao, S., Sternini, C. \& Raybould, H. E. Role of $\mathrm{CCK}_{1}$ and $\mathrm{Y}_{2}$ receptors in activation of hindbrain neurons induced by intragastric administration of bitter taste receptor ligands. Am. J. Physiol. 294, R33-R38 (2008).

84. Perez-Burgos, A. et al. Psychoactive bacteria Lactobacillus rhamnosus (JB-1) elicits rapid frequency facilitation in vagal afferents. Am. J. Physiol. 304, G211-G220 (2013).

85. Hosoi, T., Okuma, Y., Matsuda, T. \& Nomura, Y. Novel pathway for LPS-induced afferent vagus nerve activation: Possible role of nodose ganglion. Autonom. Neurosci. 120, 104-107 (2005).

86. Berthoud, H. R., Patterson, L. M., Neumann, F. \& Neuhuber, W. L. Distribution and structure of vagal afferent intraganglionic laminar endings IGLEs in the rat gastrointestinal tract. Anat. Embryol. 195, 183-191 (1997).

87. Castelucci, P., Robbins, H. L. \& Furness, J. B. P2X 2 purine receptor immunoreactivity of intraganglionic laminar endings in the mouse gastrointestinal tract. Cell Tissue Res. 312, 167-174 (2003).

88. Zagorodnyuk, V. P., Chen, B. N. \& Brookes, S. J. H. Intraganglionic laminar endings are mechano-transduction sites of vagal tension receptors in the guinea-pig stomach. J. Physiol. 534, 255-268 (2001).

89. Lynn, P. A., Olsson, C., Zagorodnyuk, V., Costa, M. \& Brookes, S. J. H. Rectal intraganglionic laminar endings are transduction sites of extrinsic mechanoreceptors in the guinea pig rectum. Gastroenterology 125, 786-794 (2003)

90. Powley, T. L. \& Phillips, R. J. Vagal intramuscular array afferents form complexes with interstitial cells of cajal in gastrointestinal smooth muscle: analogues of muscle spindle organs? Neuroscience 186, 188-200 (2011).

91. Hughes, P. A., Brierley, S. M. \& Martin, C. M. TRPV1-expressing sensory fibres and IBS: links with immune function. Gut 58, 465-466 (2009).

92. Furness, J. B., Papka, R. E., Della, N. G., Costa, M. \& Eskay, R. L. Substance P-like immunoreactivity in nerves associated with the vascular system in guinea-pigs. Neuroscience 7, 447-459 (1982).

93. Holzer, P. Role of visceral afferent neurons in mucosal inflammation and defense. Curr. Opin. Pharm. 7, 563569 (2007).

94. Ness, T. J. \& Gebhart, G. F. Visceral pain: a review of experimental studies. Pain 41, 167-234 (1990).

95. Feng, B. et al. Long-term sensitization of mechanosensitive and -insensitive afferents in mice with persistent colorectal hypersensitivity. Am. J. Physiol. 302, G676-G683 (2012).

96. Ray, B. S. \& Neill, C. L. Abdominal visceral sensation in man. Ann. Surg. 126, 709-724 (1947).

97. Bingham, J. R., Ingelfinger, F. J. \& Smithwick, R. H. The effect of sympathectomy on abdominal pain in man. Gastroenterology 15, 18-31 (1950).

98. Furness, J. B. The enteric nervous system and neurogastroenterology. Nat. Rev. Gastroenterol. Hepatol. 9 , 286-294 (2012)

99. Szurszewski, J. H. \& Miller, S. M. in Physiology of the Gastrointestinal Tract (ed. Johnson, L. R.) 795-877 (Raven Press, New York, 1994).

100. Edholm, T. et al. Differential incretin effects of GIP and GLP-1 on gastric emptying, appetite, and insulinglucose homeostasis. Neurogastroenterol. Motil. 22, 1191-e315 (2010).

101. Pocai, A. Unraveling oxyntomodulin, GLP1's enigmatic brother. J. Endocrinol. 215, 335-346 (2012).

102. Gershon, M. D. \& Kirchgessner, A. L. Identification, characterization and projections of intrinsic primary afferent neurones of the submucosal plexus: Activity- induced expression of c-fos immunoreactivity. J. Auton. Nerv. Syst. 33, 185-187 (1991).

103. Kunze, W. A. A., Bornstein, J. C. \& Furness, J. B. Identification of sensory nerve cells in a peripheral organ, the intestine of a mammal. Neuroscience 66, 1-4 (1995).

104. Furness, J. B., Jones, C., Nurgali, K. \& Clerc, N. Intrinsic primary afferent neurons and nerve circuits within the intestine. Prog. Neurobiol. 72, 143-164 (2004).

105. Kunze, W. A. A., Furness, J. B., Bertrand, P. P. \& Bornstein, J. C. Intracellular recording from myenteric neurons of the guinea-pig ileum that respond to stretch. J. Physiol. 506, 827-842 (1998).

106. Smith, T. K., Spencer, N. J., Hennig, G. W. \& Dickson, E. J. Recent advances in enteric neurobiology: mechanosensitive interneurons. Neurogastroenterol. Motil. 19, 869-878 (2007).

107. Mazzuoli, G. \& Schemann, M. Mechanosensitive enteric neurons in the myenteric plexus of the mouse intestine. PLOS ONE 7, e39887 (2012).

108. Beyak, M. J. Visceral afferents-Determinants and modulation of excitability. Autonom. Neurosci. 153, 69-78 (2010).

109. Camilleri, M. Review article: new receptor targets for medical therapy in irritable bowel syndrome. Aliment. Pharmacol. Ther. 31, 35-46 (2009).

110. Blackshaw, L. A., Page, A. J. \& Young, R. L. Metabotropic glutamate receptors as novel therapeutic targets on visceral sensory pathways. Front. Neurosci. 5, 1-7 (2011).

111. Page, A. J., Symonds, E., Peiris, M., Blackshaw, L. A. \& Young, R. L. Peripheral neural targets in obesity. Br. J. Pharmacol. 166, 1537-1558 (2012).

112. Garcia, J. M., Friend, J. \& Allen, S. Therapeutic potential of anamorelin, a novel, oral ghrelin mimetic, in patients with cancer-related cachexia: a multicenter, randomized, double-blind, crossover, pilot study. Support Care Cancer 21, 129-137 (2013).

113. Fagarasan, S., Kawamoto, S., Kanagawa, O. \& Suzuki, K. Adaptive immune regulation in the gut: T celldependent and T cell-independent IgA synthesis. Annu. Rev. Immunol. 28, 243-273 (2010).

114. Backhed, F., Ley, R. E., Sonnenburg, J. L., Peterson, D. A. \& Gordon, J. I. Host-bacterial mutualism in 
the human intestine. Science 307, 1915-1920 (2005).

115. Cerf-Bensussan, N. \& Gaboriau-Routhiau, V. The immune system and the gut microbiota: friends or foes?

Nat. Rev. Immunol. 10, 735-744 (2010).

116. Garrett, W. S., Gordon, J. I. \& Glimcher, L. H. Homeostasis and inflammation in the intestine. Cell 140, 859-870 (2010).

117. Treiner, E. et al. Selection of evolutionarily conserved mucosal-associated invariant T cell by MR1. Nature 422, 164-171 (2003).

118. Klaasen, H. L. B. M. et al. Apathogenic, intestinal, segmented, filamentous bacteria stimulate the mucosal immune system of mice. Infect. Immun. 61, 303-306 (1993).

119. Mazmanian, S. K., Liu, C. H., Tzianabos, A. O. \& Kasper, D. L. An immunomodulatory molecule of symbiotic bacteria directs maturation of the host immune system. Cell 122, 107-118 (2005).

120. Bäckhed, F. et al. The gut microbiota as an environmental factor that regulates fat storage. Proc. Natl Acad. Sci. USA 101, 15718-15723 (2004).

121. Neutra, M. R., Mantis, N. J. \& Kraehenbuhl, J. P. Collaboration of epithelial cells with organized mucosal lymphoid tissues. Nat. Rev. Immunol. 2, 1004-1110 (2001).

122. Mowat, A. M. Anatomical basis of tolerence and immunity to intestinal antigens. Nat. Rev. Immunol. $\mathbf{3}$, 331-341 (2003)

123. Kyd, J. M. \& Cripps, A. W. Functional differences between M cells and enterocytes in sampling luminal antigens. Vaccine 26, 6221-6224 (2008).

124. Kjer-Nielsen, L. et al. MR1 presents microbial vitamin B metabolites to MAIT cells. Nature 491, 717-723 (2012).

125. Chua, W.-J. \& Hansen, T. H. Vitamins prime immunity. Nature 491, 680-681 (2012).

126. Gold, M. C. \& Lewinsohn, D. M. Co dependents: MR1 restricted MAIT cells and their antimicrobial function. Nat. Rev. Microbiol. 11, 14-19 (2013).

127. Akira, S., Uematsu, S. \& Takeuchi, O. Pathogen recognition and innate immunity. Cell 124, 783-801 (2006).

128. Dann, S. M. \& Eckmann, L. Innate immune defenses in the intestinal tract. Curr. Opin. Gastroenterol. 23, 115-120 (2007).

129. Ouellette, A. J. Paneth cells and innate mucosal immunity. Curr. Opin. Gastroenterol. 26, 547-553 (2010).

130. Vaishnava, S., Behrendt, C. L., Ismail, A. S., Eckmann, L. \& Hooper, L. V. Paneth cells directly sense gut commensals and maintain homeostasis at the intestinal host-microbial interface. Proc. Natl Acad. Sci. USA 105, 20858-20863 (2008).

131. Bevins, C. L. \& Salzman, N. H. Paneth cells, antimicrobial peptides and maintenance of intestinal homeostasis. Nat. Rev. Microbiol. 9, 356-368 (2011).

132. Abraham, C. \& Cho, J. H. Inflammatory bowel disease. N. Engl. J. Med. 361, 2066-2078 (2009).

133. Buchman, A. L., Katz, S., Fang, J. C., Bernstein, C. N. \& Abou-Assi, S. G. Teduglutide, a novel mucosally active analog of glucagon-like peptide-2 (GLP-2) for the treatment of moderate to severe Crohn's disease. Inflamm. Bowel Dis. 16, 962-973 (2010).

134. Rubio-Aliaga, I. \& Daniel, H. Peptide transporters and their roles in physiological processes and drug disposition. Xenobiotica 38, 1022-1042 (2008).

135. Smith, D. E., Clemencon, B. \& Hediger, M. A. Proton-coupled oligopeptide transporter family SLC15: Physiological, pharmacological and pathological implications. Mol. Asp. Med. 34, 323-336 (2013).

136. Hagenbuch, B. \& Gui, C. Xenobiotic transporters of the human organic anion transporting polypeptides (OATP) family. Xenobiotica 38, 778-801 (2008).

137. Thelen, K. \& Dressman, J. B. Cytochrome P450-mediated metabolism in the human gut wall. J. Pharm. Pharmacol. 61, 541-558 (2009).

138. Birlouez-Aragon, I. et al. A diet based on high-heat-treated foods promotes risk factors for diabetes mellitus and cardiovascular diseases. Am. J. Clin. Nutr. 91, 1220-1226 (2010).

139. Chen, P., Zhao, J. \& Gregersen, H. Up-regulated expression of advanced glycation end-products and their receptor in the small intestine and colon of diabetic rats. Dig. Dis. Sci. 57, 48-57 (2012).

140. Zong, $\mathrm{H}$. et al. Homodimerization is essential for the receptor for advanced glycation end products (RAGE)-mediated signal transduction. J. Biol. Chem. 285, 23137-23146 (2010).

141. Jeyabal, P. V. S., Kumar, R., Gangula, P. R. R., Micci, M.-A. \& Pasricha, P. J. Inhibitors of advanced glycation end-products prevent loss of enteric neuronal nitric oxide synthase in diabetic rats. Neurogastroenterol. Motil. 20, 253-261 (2008).

142. Sanger, G. J. \& Andrews, P. L. R. Treatment of nausea and vomiting: Gaps in our knowledge. Autonom. Neurosci. 129, 3-16 (2006).

143. Bertrand, P. P., Kunze, W. A. A., Furness, J. B. \& Bornstein, J. C. The terminals of myenteric intrinsic primary afferent neurons of the guinea-pig ileum are excited by 5-hydroxytryptamine acting at 5-hydroxytryptamine-3 receptors. Neuroscience 101, 459-469 (2000).

144. Gershon, M. D. Nerves, reflexes, and the enteric nervous system. J. Clin. Gastroenterol. 38, S184-S193 (2005).

145. Lee, J., Yamamoto, T., Hayashi, S., Kuramoto, H. \& Kadowaki, M. Enhancement of CGRP sensory afferent innervation in the gut during the development of food allergy in an experimental murine model. Biochem. Biophys. Res. Commun. 430, 895-900 (2013).

146. Lundgren, O. et al. Role of the enteric nervous system in the fluid and electrolyte secretion of rotavirus 
diarrhea. Science 287, 491-495 (2000).

147. Field, M. Intestinal ion transport and the pathophysiology of diarrhea. J. Clin. Invest. 111, 931-943 (2003).

148. Mawe, G. M., Strong, D. S. \& Sharkey, K. A. Plasticity of enteric nerve functions in the inflamed and postinflamed gut. Neurogastroenterol. Motil. 21, 481-491 (2009).

149. Feng, B., La, J. H., Schwartz, E. S. \& Gebhart, G. F. Irritable bowel syndrome: Methods, mechanisms, and pathophysiology. Neural and neuro-immune mechanisms of visceral hypersensitivity in irritable bowel syndrome. Am. J. Physiol. Gastrointest. Liver Physiol. 302, G1085-G1098 (2012).

150. Matteoli, G. \& Boeckxstaens, G. E. The vagal innervation of the gut and immune homeostasis. Gut 62, 1214-1222 (2013).

151. Thomas, C. et al. TGR5-Mediated bile acid sensing controls glucose homeostasis. Cell Metab. 10, 167177 (2009).

152. Sigalet, D. L., Wallace, L., De Heuval, E. \& Sharkey, K. A. The effects of glucagon-like peptide 2 on enteric neurons in intestinal inflammation. Neurogastroenterol. Motil. 22, 1318-e350 (2010).

153. Hyland, N. P., Sjöberg, F., Tough, I. R., Herzog, H. \& Cox, H. M. Functional consequences of neuropeptide $Y Y_{2}$ receptor knockout and $Y_{2}$ antagonism in mouse and human colonic tissues. $B r$. J. Pharmacol. 139, 863-871 (2003).

154. Cox, H. M. Peptide YY: A neuroendocrine neighbor of note. Peptides 28, 345-351 (2007).

155. Kosinski, J. R. et al. The glucagon receptor is involved in mediating the body weight-lowering effects of oxyntomodulin. Obesity 20, 1566-1571 (2012).

156. Brubaker, P. L. \& Anini, Y. Direct and indirect mechanisms regulating secretion of glucagon-like peptide-1 and glucagon-like peptide-2. Can. J. Physiol. Pharmacol. 81, 1005-1012 (2003).

157. Sandoval, D., Dunki-Jacobs, A., Sorrell, J., Seeley, R. J. \& D'Alessio, D. D. Impact of intestinal electrical stimulation on nutrient-induced GLP-1 secretion in vivo. Neurogastroenterol. Motil. http://dx.doi.org/10.1111/nmo.12152.

158. Stengel, A., Goebel, M., Wang, L. \& Taché, Y. Ghrelin, des-acyl ghrelin and nesfatin-1 in gastric X/A-like cells: Role as regulators of food intake and body weight. Peptides 31, 357-369 (2010).

159. Brubaker, P. L. A beautiful cell (or two or three?). Endocrinology 153, 2945-2948 (2012).

Acknowledgments

Work from the University of Melbourne laboratory is supported by the National Health and Medical Research

Council of Australia. We are grateful for insightful comments of J. Brock, H. Cox, J. Keast, A. Lomax and R. Young.

Author contributions

The authors contributed equally to all aspects of this article. 


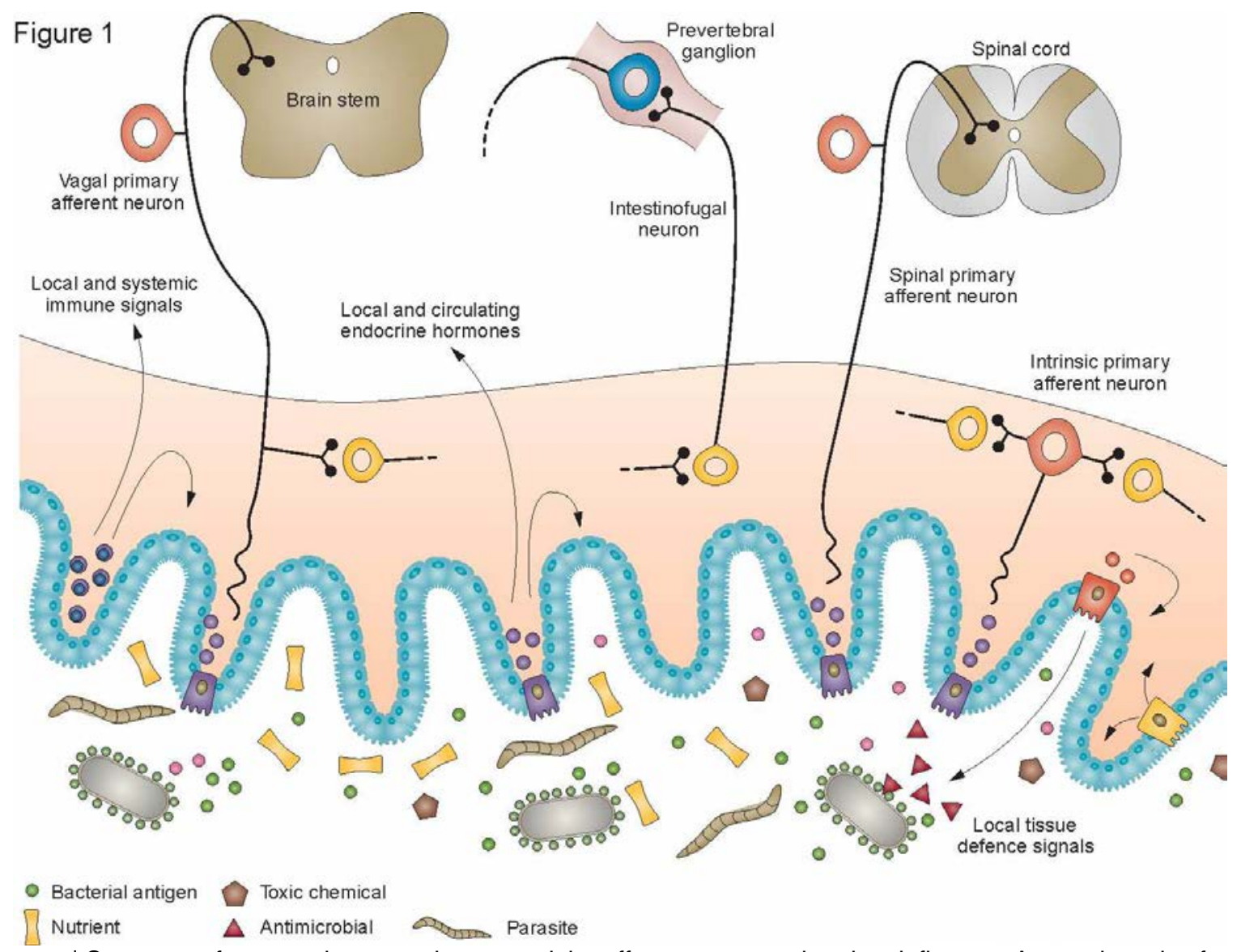

Figure 1 | Summary of sensory inputs to the gut and the effector systems that they influence. A complex mix of nutrients and their breakdown products, salts, pathogens, pathogen-derived antigens, digestive tract secretions, desquamated enterocytes, toxins and pharmaceuticals bathes the mucosa. Luminal contents activate four major effectors: the enteroendocrine system, the nervous system, the gut immune system, and the nonimmune defence system of the gut. Enteroendocrine cells (purple) in the mucosal epithelium sense luminal chemicals and release hormones that act locally on nerve endings, on enteric neurons, on the epithelium and on cells of the immune system. Hormones that enter the circulation act at remote sites. Lymphocytes are activated by antigens presented to them from the lumen. Immune cells and cells of tissue defence, such as mast cells and macrophages, also release substances that act locally within the gut wall. Some afferent neurons have cell bodies in the gut wall (intrinsic primary afferent neuron and intestinofugal neurons) and the cell bodies of others are in extrinsic ganglia (extrinsic primary afferent neurons). Bacterial products are detected by pattern-recognition receptors to activate local defence mechanisms, including secretion of antimicrobials from Paneth cells (red). Reproduced with permission from Furness, J. B. The Enteric Nervous System (Blackwell, Oxford, 2006). 
Figure 2

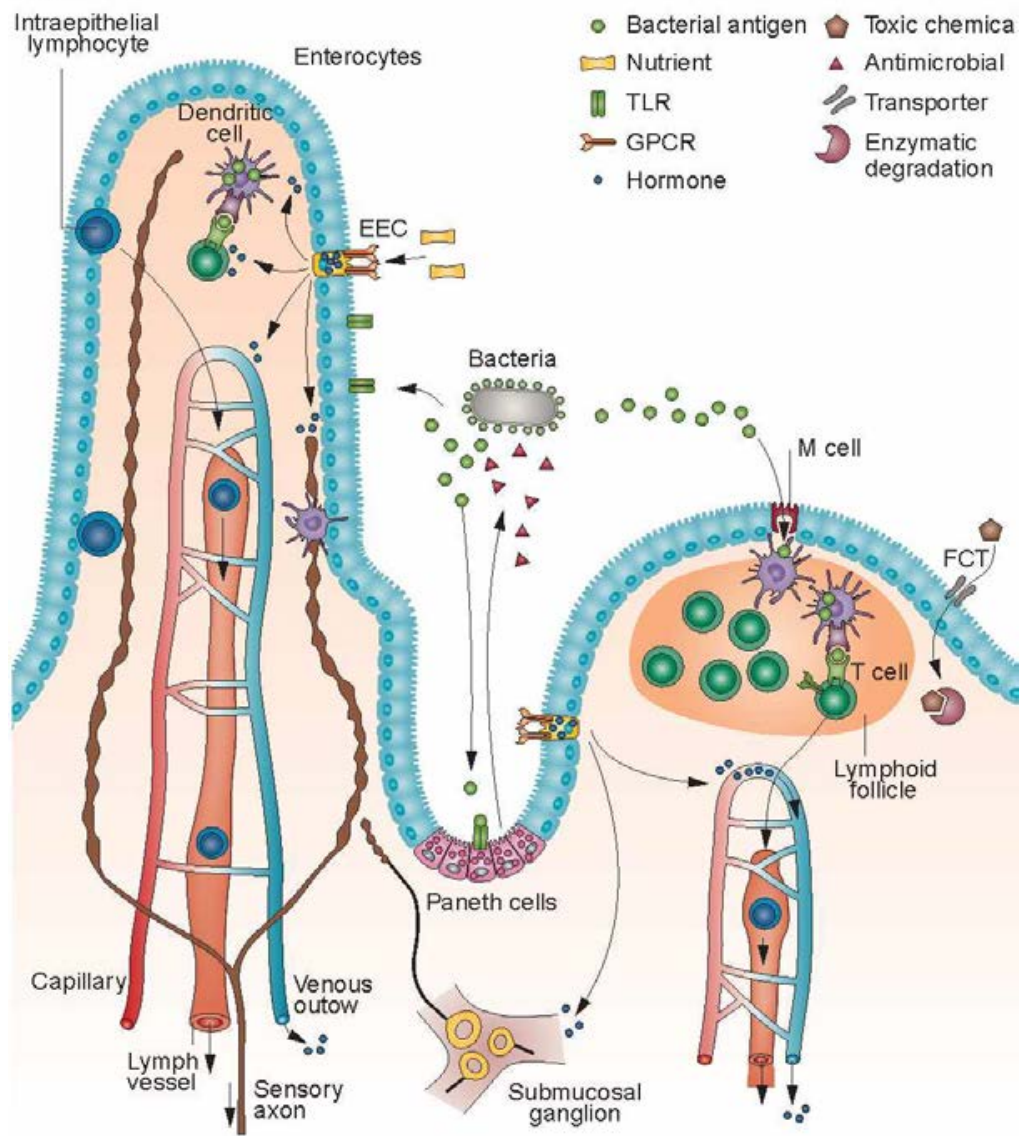

Figure 2 | Sensory systems at the lumenal interface. The intestinal lining epithelium is exposed to nutrients, which are primarily detected by receptors, most of which are GPCRs, on enteroendocrine cells. These cells release hormones that signal to the epithelium, lymphocytes, arteries and neurons locally, and which enter the circulation to act at remote sites. Presentation of antigen to Peyer's patches is mediated by $\mathrm{M}$ cells ${ }^{121}$ that sample the lumen and transfer antigen to dendritic cells. M cells probably do not process antigens themselves as they do not express MHC class II molecules, ${ }^{122}$ although they do express PRRs, including TLR4. ${ }^{123}$ Apart from M cells, the epithelium is not completely impervious to bacteria; some cross it and can be found in the wall of the intestine, in the liver and in mesenteric lymph nodes. Bacterial antigens also cross the mucosal epithelium, where they can be sampled by antigen presenting cells and exhibited to T cells. A small proportion of dendritic cells extend processes between enterocytes and probably sample the luminal contents directly. ${ }^{3}$ Products of microorganisms are also detected by PRRs, including TLRs on Paneth cells and enterocytes. Foreign molecules, including toxins and pharmaceuticals, are recognised by FCTs, transported across the epithelium and metabolised by detoxifying enzymes in the gut wall and liver. Abbreviations: EEC, enteroendocrine cell; FCTs, foreign compound transporters; GPCRs, G protein-coupled receptors; PRRs, pattern-recognition receptors; TLRs, Toll-like receptors. 


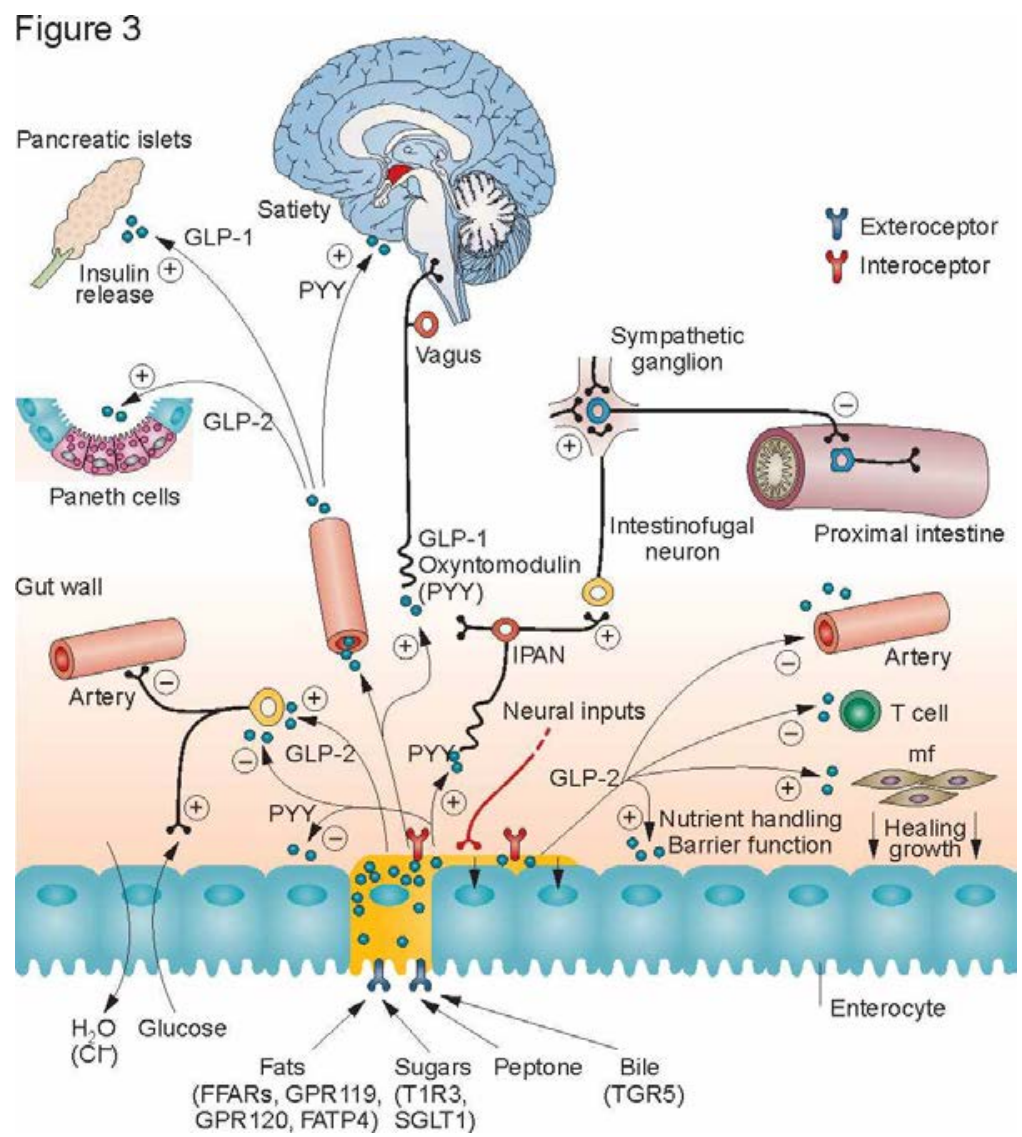

Figure 3 | Multiple sensors and multiple downstream effectors of gut sensory systems, using the $L$ cell as an example. The $L$ cell has exteroceptors for free fatty acids, sugars, protein fragments (peptone) and bile acids. These receptors face the contents of the intestine. L cells release the hormones GLP-1, GLP-2, PYY and oxyntomodulin. These hormones have actions on a range of effectors, including enterocytes, enteric neurons, vagal sensory neurons (vagus; the effect of PYY probably being indirect) and IPANs, blood vessels, lymphocytes, myofibroblasts and the hypothalamus. Downstream effects of GLP-1 on vagal afferents include slowed gastric emptying, inhibition of gastric acid secretion, stimulation of insulin release and satiety. In addition, vagal efferent pathways increase hormone release. $L$ cells have processes that run adjacent to the basal surfaces of enterocytes. $L$ cells also express interoceptors that receive signals from the internal milieu, including from neurons and hormones. Abbreviations: +, stimulation, enhancement of function; -, inhibition, including dilatation of blood vessels; FFARs, free fatty acid receptors; GLP, glucagon-like peptide; IPAN, intrinsic primary afferent neuron; mf, myofibroblast; PYY, peptide YY. 


\begin{tabular}{|c|c|c|c|c|}
\hline Cell & Products & Luminal receptors & Locations & Principal effects \\
\hline $\begin{array}{l}\text { A (X-like) cells } \\
\text { and subtypes }\end{array}$ & $\begin{array}{l}\text { Ghrelin, } \\
\text { nesfatin-1 }\end{array}$ & $\begin{array}{l}\text { T1R1-T1R3; } \\
\text { T2Rs }\end{array}$ & Stomach & $\begin{array}{l}\text { Appetite control, growth hormone } \\
\text { release }\end{array}$ \\
\hline ECL cell* & Histamine & Closed cell & Stomach & $\begin{array}{l}\text { Stimulation of gastric acid } \\
\text { secretion }\end{array}$ \\
\hline G cells & Gastrin & GPR92; GPRC6A & Stomach & $\begin{array}{l}\text { Stimulation of gastric acid } \\
\text { secretion }\end{array}$ \\
\hline D cells & Somatostatin & $\begin{array}{l}\text { GPR92; } \\
\text { GPRC6A }\end{array}$ & $\begin{array}{l}\text { Stomach, small } \\
\text { intestine (and } \\
\text { pancreas) }\end{array}$ & $\begin{array}{l}\text { Inhibition of gastrin release } \\
\text { (stomach); modulation of insulin } \\
\text { release (pancreas) }\end{array}$ \\
\hline $\begin{array}{l}\text { Enterochromaffin } \\
\text { cells }\end{array}$ & $\begin{array}{l}5-\mathrm{HT} .5-\mathrm{HT} \text { is } \\
\text { also contained in } \\
\text { subgroups of I, K } \\
\text { and L cells. }\end{array}$ & $\begin{array}{l}\text { FFARs } 2,3 \text {, } \\
\text { TRPA1; toxin } \\
\text { receptors; TLRs }\end{array}$ & $\begin{array}{l}\text { Stomach, small } \\
\text { and large } \\
\text { intestine }\end{array}$ & $\begin{array}{l}\text { Facilitation of intestinal motility } \\
\text { reflexes and secretion. } \\
\text { Triggering of emesis and nausea } \\
\text { in response to toxins }\end{array}$ \\
\hline I cells & CCK (5-HT) & $\begin{array}{l}\text { T2Rs; FFA1; } \\
\text { GPR120; GPR93; } \\
\text { CaSR; TRPA1; } \\
\text { TLRs }\end{array}$ & $\begin{array}{l}\text { Proximal small } \\
\text { intestine }\end{array}$ & $\begin{array}{l}\text { Activation of gallbladder } \\
\text { contraction and stimulation of } \\
\text { pancreatic enzyme secretion. }\end{array}$ \\
\hline $\begin{array}{l}\text { K cells, and } \\
\text { subtypes }\end{array}$ & GIP & $\begin{array}{l}\text { GPRs 119,120; } \\
\text { FFAR1 }\end{array}$ & $\begin{array}{l}\text { Proximal small } \\
\text { intestine }\end{array}$ & Stimulation of insulin release \\
\hline $\begin{array}{l}\text { L cells, and } \\
\text { subtypes }\end{array}$ & $\begin{array}{l}\text { GLP-1, GLP-2, } \\
\text { PYY, } \\
\text { oxyntomodulin } \\
\text { (5-HT) }\end{array}$ & $\begin{array}{l}\text { T2Rs; } \\
\text { T1R2/T1R3; } \\
\text { FFARs 1, 2, 3; } \\
\text { GPRs119, 92/93, } \\
\text { 120; CaSR }\end{array}$ & $\begin{array}{l}\text { Distal small } \\
\text { intestine, colon }\end{array}$ & $\begin{array}{l}\text { Stimulation of carbohydrate } \\
\text { uptake, slowing of intestinal } \\
\text { transit, appetite regulation }\end{array}$ \\
\hline M cells & Motilin $^{\mp}$ & Bile receptors & Small intestine & $\begin{array}{l}\text { Initiation of migrating myoelectric } \\
\text { complex in pig, dog and human. }\end{array}$ \\
\hline $\mathrm{N}$ cells & Neurotensin $^{8}$ & FFARs & $\begin{array}{l}\text { Small and large } \\
\text { intestine }\end{array}$ & $\begin{array}{l}\text { Inhibition of intestinal } \\
\text { contractions }\end{array}$ \\
\hline $\mathrm{P}$ cells & Leptin & Nutrient receptors & Stomach & $\begin{array}{l}\text { Appetite regulation, reduction of } \\
\text { food intake. Leptin may also be } \\
\text { in chief cells. }\end{array}$ \\
\hline S cells & Secretin & Acid receptor & $\begin{array}{l}\text { Proximal small } \\
\text { intestine }\end{array}$ & $\begin{array}{l}\text { Reduction of acidity in upper } \\
\text { small intestine by stimulation of } \\
\text { bicarbonate release. }\end{array}$ \\
\hline \multicolumn{5}{|c|}{$\begin{array}{l}\text { Several of the enteroendocrine cell types, notably } \mathrm{A}, \mathrm{K} \text { and } \mathrm{L} \text { cells, have subgroups or gradients along the } \\
\text { intestine that contain different combinations of products; subgroups of I and } \mathrm{L} \text { cells contain } 5-\mathrm{HT} \text {. } 158,159 \\
\text { Moreover, overlaps between } \mathrm{N} \text { and } \mathrm{S} \text { cells and I, } \mathrm{K} \text { and } \mathrm{L} \text { cells are observed. *ECL cells do not contact the } \\
\text { lumen. }{ }^{\ddagger} \text { bile is an effective stimulus for motilin release, but the receptor type is not identified. }{ }^{\S} \text { Short and medium } \\
\text { chain fatty acids cause neurotensin release, but the receptor type of } \mathrm{N} \text { cells is not identified. Abbreviations: ECL, } \\
\text { enterochromaffin-like cells; FFAR, free fatty acid receptor; } 5-\mathrm{HT} \text {, serotonin; TLR, Toll-like receptors. }\end{array}$} \\
\hline
\end{tabular}




\section{Box 1 | Factors sensed in gut lumen and associated receptors*}

\section{Nutrients and food components}

The taste receptors: Simple sugars and artificial sweeteners, the sweet taste receptor, T1R2-T1R3; amino acids, the umami (savoury) receptor, T1R1-T1R3; the bitter receptor family, T2Rs; the sour (acid) receptor, PKD2L1.

Carbohydrates: T1R2-T1R3, SGLT1, T1R3 (not dimerized with T1R2)

Protein breakdown products (peptones and amino acids): CaSR, GPR92/93, GPRC6A, T1R1-T1R3

Free fatty acid receptors: free fatty acid receptors 1-3, GPR119, GPR120

Phytochemicals (specific chemical entities of herbs and spices): transient receptor potential (TRP) receptors, including TRPV1, TRPV2, TRPV5, TRPV6, TRPA1, TRPP2 (PKD2L1); the bitter receptor, T2R; olfactory receptors

Mechanical distortion, stretch and tension

Mechanosensitive channels of nerve endings and enteroendocrine cells

Other physicochemical attributes

Temperature, osmolarity, acidity

Internal secretions

Bile acid receptors, TGR5

Bacteria, viruses, fungi, protozoa and helminths: their antigens and products

Pattern recognition receptors: Toll-like receptors 1-9, NOD1, NOD2

T-cell receptors: peptides, lipopolysaccharides, vitamin B metabolites

\section{Toxins and emetogenic compounds}

Receptors for emetogenic toxins on 5-HT-containing enteroendocrine cells in the stomach and proximal small intestine Receptors for advanced glycation end products

*where known 


\section{University Library}

\section{- M M I E R R V A gateway to Melbourne's research publications}

Minerva Access is the Institutional Repository of The University of Melbourne

Author/s:

Furness, JB;Rivera, LR;Cho, H-J;Bravo, DM;Callaghan, B

Title:

The gut as a sensory organ

Date:

2013-12-01

Citation:

Furness, J. B., Rivera, L. R., Cho, H. -J., Bravo, D. M. \& Callaghan, B. (2013). The gut as a sensory organ. NATURE REVIEWS GASTROENTEROLOGY \& HEPATOLOGY, 10 (12), pp.729-740. https://doi.org/10.1038/nrgastro.2013.180.

Persistent Link:

http://hdl.handle.net/11343/59318 